\title{
Harnessing values to save the rhinoceros: insights from Namibia
}

\author{
Jeff R. Muntifering, Wayne L. Linklater, Susan G. Clark, Simson ! Uri- $\neq$ Khob \\ John K. Kasaona, Kenneth / Uiseb, Pierre Du Preez, Kapoi Kasaona \\ Petrus Beytell, Jermain Ketji, Boas Hambo, Matthew A. Brown \\ Chris Thouless, Shayne Jacobs and Andrew T. Knight
}

\begin{abstract}
The rate at which the poaching of rhinoceroses has escalated since 2010 poses a threat to the long-term persistence of extant rhinoceros populations. The policy response has primarily called for increased investment in militarystyle enforcement strategies largely based upon simple economic models of rational crime. However, effective solutions will probably require a context-specific, stakeholder-driven mix of top-down and bottom-up mechanisms grounded in theory that represents human behaviour more realistically. Using a problem-oriented approach we illustrate in theory and practice how community-based strategies that explicitly incorporate local values and institutions are a foundation for combating rhinoceros poaching effectively in specific
\end{abstract}

Jefr R. Muntifering*† (Corresponding author) Minnesota Zoo, 13000 Zoo Blvd, Apple Valley, Minnesota, 55124 USA. E-mail jeff.muntifering@state.mn.us

WAYNE L. LiNKLATER $\ddagger$ Centre for Biodiversity and Restoration Ecology, School of Biological Sciences, Victoria University of Wellington, New Zealand

Susan G. Clark School of Forestry and Environmental Studies, Institution for Social and Policy Studies, Yale University, New Haven, USA, and Northern Rockies Conservation Cooperative, Jackson, USA

SIMSON !URI- $\neq$ Кнов Save the Rhino Trust, Swakopmund, Namibia

JoHn K. KasaOna Integrated Rural Development and Nature Conservation, Windhoek, Namibia

Kenneth /Uiseb, Pierre Du Preez and Petrus Beytell Ministry of Environment and Tourism, Windhoek, Namibia

KaPOI KaSAONa Anabeb Conservancy, Kamanjab, Namibia

Jermain KetjI Wilderness Safaris, Windhoek, Namibia

Boas Hambo Conservancy Safaris Namibia, Swakopmund, Namibia

Matthew A. Brown The Nature Conservancy, Africa Regional Office, Arusha, Tanzania

Chris Thouless Conservancy Development Support Services, World Wildlife Fund, Windhoek, Namibia

SHAYNE JACOBS Department of Conservation Ecology and Entomology, Stellenbosch University, Matieland, South Africa

ANDREW T. KNIGHTS Department of Life Sciences, Imperial College London, Silwood Park Campus, Ascot, UK

${ }^{*}$ Also at: Save the Rhino Trust, Swakopmund, Namibia

$\dagger$ Also at: Department of Conservation Ecology and Entomology, Stellenbosch University, Matieland, South Africa

¥Also at: Department of Zoology, Centre for African Conservation Ecology, Nelson Mandela Metropolitan University, Port Elizabeth, South Africa

$\$$ Also at: Department of Botany, Nelson Mandela Metropolitan University, Port Elizabeth, South Africa, and ARC Centre of Excellence in Environmental Decisions, The University of Queensland, St Lucia, Australia

Received 26 January 2015. Revision requested 24 March 2015. Accepted 8 June 2015. First published online 28 September 2015. contexts. A case study from Namibia demonstrates how coupling a locally devised rhinoceros monitoring regime with joint-venture tourism partnerships as a legitimate land use can reconcile individual values represented within a diverse stakeholder group and manifests as both formal and informal community enforcement. We suggest a social learning approach as a means by which international, national and regional governance can recognize and promote solutions that may help empower local communities to implement rhinoceros management strategies that align individual values with the long-term health of rhinoceros populations.

Keywords Community-based conservation, conservation tourism, incentives, poaching, policy, rhinoceros, values

\section{Introduction}

The rate at which the poaching of rhinoceroses has 1 escalated (Knight, 2012) since 2010 poses a threat to the long-term persistence of extant rhinoceros populations (Duffy et al., 2013). Resurgent global trade and unprecedented black market prices for rhinoceros horn are implicated as the major drivers of the killing (Ferreira \& Okita-Ouma, 2012; Biggs et al., 2013). Although rhinoceros conservation scientists and practitioners promote a variety of strategies to safeguard the rhinoceros (Duffy et al., 2013), military-style law enforcement and demand reduction (Ferreira \& Okita-Ouma, 2012; Biggs, 2013; Challender \& MacMillan, 2014; IUCN et al., 2015) have dominated the response to protect Africa's remaining 20,000 white rhinoceros Ceratotherium simum and 5,000 black rhinoceros Diceros bicornis. Despite courageous efforts to combat poaching, and some positive trends in end-user behaviour (Coghlan, 2014), rhinoceros poaching rates continue to rise, with a reported $184 \%$ increase across Africa during 2008-2012 (Standley \& Emslie, 2013). We investigated what and how community-based strategies make military-style protection more effective but also provide innovative, longer-term solutions that are more resilient to the changing type and magnitude of threat. We use the Namibian experience to make a case for rhinoceroses and other wildlife as a legitimate land use that embodies both collective and individual values, creating the social foundation that enforcement-based strategies 
require to be successful. This is preferable to the prioritization of military-style strategies, and more successful. Although we affirm that effective and reliable rhinoceros protection should be supported by governmental enforcement, we illustrate both in theory and practice that investing in community-based strategies that are founded explicitly on local values and rights, and facilitated through locally devised institutions, can improve our collective efforts to combat rhinoceros poaching.

\section{What is the problem?}

Rhinoceros poaching is a complex problem (Rittel \& Webber, 1973; Brown et al., 2010) that is interconnected with other problems across multiple scales, making solutions elusive. Military-style protection strategies focus narrowly on poaching (Ferreira \& Okita-Ouma, 2012) and often cause anger, resentment and a sense of disenfranchisement among local people (Dowie, 2009). This approach does not contextualize the problem, and reinforces fortress conservation, a product of Africa's late-colonial and independence history that reserved wild areas primarily for European leisure activities (Adams \& Hulme, 2001; Brockington, 2002). Military-style protection, which is sometimes promoted by transnational conservation organizations (Dowie, 2009), tends to reinforce the benefits of biodiversity for powerful local and international elites. Fortress conservation has had significant political, social and cultural effects on indigenous people, including restricted access to, or exclusion from, both policy processes and areas important for their livelihood and cultural practices, and sometimes even physical relocation (Dowie, 2009). The erosion of culture, language and ultimately human dignity has resulted in retaliatory illegal hunting and other unsustainable use of resources, often referred to by conservationists as poaching (Sullivan \& Homewood, 2004; Dowie, 2009). Thus, the response to conflict with local people, who are typically framed by conservationists as being part of the problem, has often been to tighten control through more weapons, fences and fines (Dowie, 2009). This approach has resulted in mistrust and a sense of alienation among local people, and established barriers that compromised local support for conservation; for example, resettlement plans for communities residing in Mozambique's Limpopo National Park caused anger and distrust (Dressler \& Büscher, 2008; Milgroom \& Spierenburg, 2008) and may have contributed to the upsurge in poaching in neighbouring South Africa's Kruger National Park. In some cases, measures to increase militarization of government-led enforcement and anti-poaching activity have undermined the efforts of conservationists working to build trust and cooperation with communities (IUCN et al., 2015).

The social injustices of fortress conservation have inhibited multi-stakeholder responses to the poaching problem. Addressing these injustices in the search for solutions will require a shift in the way practitioners orient themselves to natural resource management problems, and a broadening of perspective. Motivational instruments are fundamental in fostering positive changes in local attitudes and behaviours that align with conservation objectives and facilitate collective action (Berkes, 2004). Whereas the military-style approach to governance typically does not enrich or motivate local people, illicit trade and organized crime often do, to the extent that marginal increases in security investment and effectiveness are unlikely to be a significant deterrent; for example, a sworn affidavit from a poaching case in north-west Namibia indicates that poaching syndicates offer up to three times the mean annual household income (National Planning Commission, 2007) for a single set of rhinoceros horns. Models of speculative behaviour suggest that when in situ population numbers approach the minimum viable population size (as is the case with the black rhinoceros) it is more profitable for buyers to collude by employing a 'bank on extinction' strategy than to reduce consumption. Banking on extinction encourages an increase in poaching to extirpate the species in the wild while achieving a private stockpile monopoly scenario to maximize returns (Mason et al., 2012). Thus, without appropriate incentives to motivate compliance with government-imposed regulation and conservation objectives it is not surprising that in most cases local communities are unable or unwilling to stem the tide of organized criminal poaching, and are sometimes complicit in poaching activity. Lasting solutions depend on the availability of adequate resources, and changing the behaviour of local people in a manner that promotes rhinoceros conservation.

The poaching problem is often framed as a war against criminals, with response strategies seeking to catch poachers (Neumann, 2004). We suggest reframing the problem through two pragmatic questions: (1) What mix of instruments, incentives and institutions could maximize the values local people attach to conserving the rhinoceros? (2) Who decides how rhinoceroses are managed? This framing shifts the focus from militaristic to community-based approaches, acknowledging the complex systems in which multiple stakeholders operate. Solutions emanating from this approach will promote strategies that keep poaching from becoming a normative behaviour. We make a case for initiating behavioural change in local communities by developing an economic and socio-political relationship between the rhinoceros and local communities that harnesses human values to deliver greater return on investment for rhinoceros conservation initiatives.

\section{Behavioural change: more than just deterrence}

In addition to detection and prevention, military-style enforcement attempts to change behaviour by means of 
coercion, in the belief that threats and punishment will deter rule-breaking behaviour. Knowingly or not, these strategies are based on a simple model of rational crime; that is, crime results when an individual chooses to contravene rules where the benefits are perceived to be greater than the costs of their rule-breaking behaviour (Becker, 1968). When applied to rhinoceros poaching, this model assumes that poachers consider the anticipated financial benefits directly against the risk of being caught and the severity of potential punishment (Milner-Gulland \& Leader-Williams, 1992). More recent expansions of the model explicitly incorporate a poacher's ability to calculate and trade-off the benefits of poaching against the likelihood of being shot and killed (Messer, 2010). However, observations and experimentation suggest that human behaviour, including acts of dishonesty, is typically not an outcome of a simple, rational cost-benefit analysis (Kahneman, 2011; Ariely, 2012; Shogren, 2012).

Criminal and dishonest behaviour in general is a product of influences more complex and fundamental to an individual's decision making than those comprising a purely rational economic cost-to-benefit trade-off. Values are the basic medium of exchange in all human interactions and underline the things and events that people desire and demand (Lasswell, 1971). People seek to shape and share values through exchanges structured on the norms embedded within societal institutions (Lasswell \& Holmberg, 1992), which have a significant influence on behaviour (Keane et al., 2008; Kahler \& Gore, 2012). Relationships, norms and values reduce the likelihood of individuals acting in their short-term self-interest (Ostrom, 2000). Mattson et al. (2012) provide an overview within a natural resource management and policy context of two dominant value concept schemes (Lasswell, 1943; Schwartz \& Bilsky, 1987), with reference to Maslow's hierarchy of needs (Maslow, 1954). Each scheme has its own merits but we adopt Lasswell's policy-oriented value concept because it creates an explicit linkage between values and institutions, which we feel is critical in the context of rhinoceros conservation. Lasswell's value classification states human motivations are underpinned by personal, group and institutional values and can be categorized, regardless of age, gender, nationality or culture, as power, wealth, respect, well-being, affection, rectitude, skills or intelligence (Lasswell, 1971; Clark, 2002), and people use these base values to accumulate other sought-after values through institutions that use and have an impact on resources (Lasswell, 1971). Changing how the rhinoceros is valued, while developing or strengthening local institutions that embody these values, can become the basis for a shift in social norms, even after rhinoceros poaching has become a normative behaviour.

Other approaches that may be used to understand the complex factors that drive human behaviour include the theory of planned behaviour (Ajzen, 1991), value-belief-norm theory (Stern et al., 1999), and insights from conservation psychology on community-based social marketing (McKenzie-Mohr, 200o) and pro-environmental behaviour, including bounded rationality, willpower and self-interest (Steg \& Vlek, 2009; Shogren, 2012). These may be applied to understand why poaching occurs and to design more effective and cost-efficient strategies for rhinoceros conservation.

Social capital is also critical to the power and continuity of social values and norms. Trust, cooperation and mutual support provide the foundation for the civil discourse required to secure solutions in the common interest (Putnam, 2000) and make values and norms explicit, agreed and observed. Social values, norms and capital commonly explain pro-environmental behaviour and collective action (Ostrom, 2000). Coercive deterrence of illicit behaviour does not harness the values and norms of local communities or have positive outcomes for social capital; for example, incarcerated community members can reduce social capital by breaking relationships or creating financial dependencies that may motivate retribution and retaliatory action. Strategies that recognize individual and communal values, harness normative behaviour, and invest in social capital are likely to hold greater promise for changing and sustaining pro-rhinoceros behaviour.

\section{Increasing local intolerance to poaching}

Top-down rule making and enforcement that ignores local norms and institutions can produce negative outcomes, particularly where government and law enforcement officials lack the necessary resources for effective implementation (Lejano et al., 2007). Conversely, monitoring and enforcement systems that are devised and build capacity at the local level have been found to be more successful over longer time periods (Berkes et al., 2006; Ostrom, 2007). Military-style responses are understandable and necessary but could deliver more effective conservation if they were motivated by and incorporated local values. A balance between top-down military-style strategies and bottom-up community-based mechanisms is needed to ensure behaviour in the common interest prevails over individuals' short-term financial gains. Fundamental to this rebalancing is the need for our understanding of human behaviour to be applied within a practical decision making framework. Engaging established frameworks from the policy sciences can provide a comprehensive understanding of rhinoceros poaching across multiple temporal and spatial scales (Clark, 2002).

Understanding the individual and community values that motivate pro-conservation behaviour is central to solving natural resource management problems. Common-interest solutions require that resources (e.g. rhinoceros horn) are used and managed through local institutions, which is a 
critical factor in reducing over-exploitation, excluding roving bandits (Ostrom, 1990; Berkes et al., 2006) and mobilizing local support for rhinoceros conservation. Thus, an optimal combination of instruments, incentives and institutions that promote pro-rhinoceros behaviour should ensure that community values and the institutions within which they are shaped and shared are maintained or enhanced.

\section{Namibia's practice-based approach}

Namibia's community-based natural resource management programme was founded and formalized in the mid $1990 \mathrm{os}$ following a series of socio-ecological surveys with residents of communal land, and policy reform that would return rights over wildlife and tourism to these residents through the establishment of a common property regime called a conservancy (Jones \& Murphree, 2001). Based on Ostrom's design principles for effective, sustainable common property natural resource management institutions (Jones, 2010), Namibia's community-based natural resource management framework seeks to create conditions that promote proconservation behaviour by rural communities. This is achieved primarily through provision of property rights and incentives through locally accrued and distributed benefits from wildlife and tourism (MET, 2013). Benefits are typically realized in power-sharing or financial terms whereby rural residents registered with a gazetted conservancy receive clearly defined, conditional user rights over wildlife and tourism development (Jones et al., 2015). These devolved rights have been used to help secure significant local income and jobs. In 2013 communal conservancies received NAD $72,200,000$ (c. USD 6.5 million) and facilitated 6,472 jobs through 167 joint ventures with conservancies (NACSO, 2014). To date, 79 conservancies have been registered in Namibia, incorporating $8.3 \%$ of the population $(>175,000$ people) and $19.4 \%$ of the land area (c. 16 million ha; NACSO, 2014). Although not without criticism (Sullivan, 2002; Hoole, 2010), these conservancies have probably contributed to a decrease in poaching (Owen-Smith, 2010) and a general widespread increase in wildlife on communal land, including threatened mammals such as the black-faced impala Aepyceros melampus petersi, Hartmann's mountain zebra Equus zebra hartmannae, cheetah Acinonyx jubatus, lion Panthera leo and black rhinoceros (IUCN, 2014; NACSO, 2014).

Collaborative efforts to establish local value-based institutions that secure the common interest in conserving the black rhinoceros were initiated formally in north-west Namibia in the early 1980s (Owen-Smith, 2010) and included a locally devised and managed auxiliary game guard system (Loutit \& Owen-Smith, 1989). A series of stakeholder engagement workshops helped strengthen the foundation for long-term strategic partnerships between government, local communities, NGOs and, more recently, private-sector tourism operators, based on a recognition and understanding of local values, perspectives and desired outcomes for rhinoceros conservation (Hearn et al., 2004). Namibia's community-oriented approach has helped to instil in local communities a sense of ownership and acceptance of the rhinoceros, despite all black rhinoceroses being owned by the state (!Uri- $\neq$ Khob, 2004).

In 2005 the innovative Rhino Custodianship Programme established by Namibia's Ministry of Environment and Tourism spearheaded a large-scale initiative to achieve biological management and rural development goals by restoring the black rhinoceros to its historical rangelands while meeting an emerging demand from local communities to engage in rhinoceros tourism (!Uri- $\neq$ Khob et al., 2010). This provided an opportunity to strengthen existing local values and institutions that supported rhinoceros conservation, demonstrated by the government's willingness to share key values identified by communities, including power (through the establishment of co-management institutions that have granted custodial rights to landholders or communal conservancies that wish to utilize the rhinoceros for tourism on their land), wealth (through rights for local people to benefit from non-consumptive use of rhinoceroses, without any requirement to share profits with central government) and respect (through assigning joint responsibility for local conservation activities). Other values sought by local people, notably skills, knowledge and well-being, have been fulfilled through partnerships with local and international NGOs, and with tourism operators that have contributed towards rhinoceros conservation, especially through co-financing rhinoceros monitoring. Since the reform of Namibia's community-based conservation policy in the mid 1990s (Owen-Smith, 2010), and the adoption and expansion of joint-venture tourism enterprises, the rhinoceros population has more than doubled (Beytell \& Muntifering, 2009) and sustained consistent positive growth rates (Brodie et al., 2011) despite persisting almost entirely on formally unprotected lands. Although $51 \%$ of the rhinoceros population persists on communal conservancy land, only 4 of the 18 confirmed incidents of poaching in 2014 occurred in these areas (Muntifering et al., 2015).

Designing a tourism product that serves as an effective community-based conservation mechanism requires reconciling the individual values of a diverse group of stakeholders, in particular those of local communities. The rhinoceros tourism model developed in north-west Namibia has evolved through learning what approaches are effective in practice, and through an inclusive and comprehensive decision making process. Aligned with conservation tourism principles (Buckley, 2010), best practices have been developed to minimize disturbance of rhinoceroses, maintain tourist satisfaction, and sustain sufficient profit to produce net conservation benefits. Allowing local 
trackers to showcase their tracking skills and local knowledge has instilled a sense of pride in traditional skills and rhinoceros protection. In one conservancy, benefits from rhinoceros tourism have significantly improved local attitudes towards rhinoceroses (/Uiseb, 2007), and intolerance of poaching has contributed towards formal and informal community enforcement. In December 2012 a rhinoceros poacher was identified, apprehended, arrested and had a firearm and horns confiscated within 24 hours of the discovery and immediate reporting of the carcass by a local farmer near the north-east boundary of the Palmwag Tourism Concession Area. Tourism initiatives currently finance ongoing monitoring of $25 \%$ of Namibia's north-west freeranging rhinoceroses. Of the 18 confirmed cases of rhinoceros poaching that have occurred in north-west Namibia during 2012-2014, none were in an area where rhinoceros tourism is practised, or in a conservancy wildlife tourism area with permanent activity and direct benefitsharing agreements between the private sector operator and the host conservancy.

As the demand for rhinoceros tourism opportunities increases it will become essential to design and implement benefit-sharing mechanisms that ensure security, quality monitoring, and community support for rhinoceroses. One promising policy intervention that has emerged through an extended social context mapping of local values (Clark, 2002) has been the development of a conservancy-led rhinoceros ranger initiative. Since 201226 rangers have been appointed by and accountable to $13 \mathrm{com}$ munal conservancies. These Conservancy Rhino Rangers have been provided with training, state-of-the art monitoring equipment and field gear, and performance-based bonus payments to improve the quantity and quality of conservancy-led rhinoceros patrols (Muntifering et al., 2015). The number of trained, equipped rhinoceros monitoring personnel in Namibia's north-west has tripled since 2012 and the number of conservancies actively engaged in monitoring has increased twelve-fold; in 2014 there were 1,013 ranger patrol days and 727 rhinoceros sightings by rangers in the 13 participating conservancies.

The sustainability of the initiative will depend on an institutional arrangement ensuring that the benefits from rhinoceros tourism return to the conservancy. Under a user-pays principle the local communities that bear the monitoring and opportunity costs of rhinoceros conservation would receive royalty payments. The initiative would thus not only enhance the quality and quantity of community-led monitoring efforts but would also reinforce rhinoceros tourism as a legitimate and profitable land use. Successful implementation will require an integrated, comprehensive, inclusive and transparent decision-making process that includes planning, open debate, and setting rules and guidelines that secure the common interest (Clark, 2002). Rigorous appraisals of contextual, practice-based prototypes will help facilitate the identification of best practices (Hohl \& Clark, 2010), quantify causal effects (Ferraro \& Hanauer, 2014), and apply lessons learned to evolving contexts.

\section{Let the locals lead}

Understanding local perspectives and values is fundamental to solving complex natural resource management problems effectively (Clark, 2002). Yet the top-down command and control approach, with associated emphasis on military-style regulatory and enforcement strategies, continues to drive the discourse in the search for solutions to poaching (Biggs, 2013; Challender \& MacMillan, 2014). We recognize that law enforcement is critical to effective prevention of wildlife crime but our experience in Namibia suggests that bolstering investments that seek to engage and empower local communities in rhinoceros protection efforts will probably yield greater returns than continuing to focus narrowly on fighting fire with fire. However, shifting our priorities will probably require a reassessment of how we orient ourselves to the poaching problem and the theories we apply towards devising strategies. To do this we need to unlearn much of what traditional economic theory and the simple model of rational crime have taught us regarding how people think and behave, by acknowledging the evidence, embracing new insights on human decision making from behavioural economics and applying them to conservation problems (Cowling, 2014). By refocusing from a simplistic cost-benefit world view to incorporating cognitive, emotional and social factors, in particular values and institutions, to drive behavioural change, longer-term solutions can be developed.

We have argued for the role of values, norms, social capital and institutions in changing the pay-off structures of wildlife crime, and illustrated its application in north-west Namibia. Although much of the theory is universally transferable in terms of both location and target species, it should be noted that this case study is context-specific and may be influenced by contextual factors such as the region's high tourism draw, low human population density, arid and rugged terrain less suitable for domestic livestock, and cohesive social and institutional networks. Replication in other locations may be confounded by different political, social and ecological environments. We therefore emphasize that harnessing local community values to save the rhinoceros should not be viewed as a universal panacea for poaching but rather as a fundamental factor that provides the necessary social foundation for other policy instruments, incentives and institutions (Young \& Gunningham, 1997). Policies that do not engage, empower and benefit local communities living alongside rhinoceroses will have limited success. We assert the fundamental importance of letting 
the locals lead (Smith et al., 2009), as it has been demonstrated that the long-term effectiveness of biodiversity conservation programmes depends on the support of local people, the ability to harness local knowledge and cooperative capacity, and the degree to which solutions are devised and owned by local people (Young \& Gunningham, 1997; Ostrom, 2000, 2007; Berkes, 2004; Lejano et al., 2007; Brooks et al., 2012).

Although solutions ultimately depend on creating and sustaining pro-rhinoceros behaviour at the local level, the problem must be addressed at multiple scales (Berkes, 2007). International, regional, national (notably major horn markets and rhinoceros range countries) and local governance bodies need to recognize and promote local governance and resource rights regimes that align individual self-interest with the long-term health of rhinoceros populations (Berkes et al., 2006). This may best be achieved through a social learning process that disseminates information on a regular basis to solve the problem in a way that is consistent with local practices. Such a multi-tiered approach will help design and deliver bottom-up strategies underpinned by human values and facilitated through local institutions that, when combined with top-down regulation, will be more effective in securing a future for the rhinoceros.

\section{Acknowledgements}

We thank Namibia's Ministry of Environment and Tourism for having the foresight and courage to share values with local communities as a means to secure a future for Namibia's rhinoceros population. We acknowledge the ground-breaking work conducted in the 1980s and 1990 s by the many committed individuals that opposed the conventional exclusionary conservation paradigm of the time. We thank Michael Soulé, Raoul du Toit, Philip Nyhus, Tara Harris and two anonymous referees for providing useful comments and insights. Most importantly, we credit the local people who live alongside rhinoceroses in north-west Namibia for making the decision that rhinoceroses are more valuable alive than dead.

\section{References}

Adams, W.M. \& Hulme, D. (2001) Conservation and community: changing narratives, policies and practices in African conservation. In African Wildlife \& Livelihoods: The Promise and Performance of Community Conservation (eds D. Hulme \& M. Murphree), pp. 9-23. Heinemann, Portsmouth, USA.

Ajzen, I. (1991) The theory of planned behavior. Organizational Behavior and Human Decision Processes, 50, 179-211.

Ariely, D. (2012) The Honest Truth about Dishonesty. HarperCollins Publishers, New York, USA.

BECKER, G.S. (1968) Crime and punishment: an economic approach. Journal of Political Economy, 76, 169-217.
BERKES, F. (2004) Rethinking community-based conservation. Conservation Biology, 18, 621-630.

Berkes, F. (2007) Community-based conservation in a globalized world. Proceedings of the National Academy of Sciences of the United States of America, 104, 15188-15193.

Berkes, F., Hughes, T.P., Steneck, R.S., Wilson, J.A., Bellwood, D.R., Crona, B. et al. (2006) Globalization, roving bandits, and marine resources. Science, 311, 1557-1558.

Beytell, P. \& Muntifering, J.R. (2009) West Kunene Black Rhino Census. Save the Rhino Trust, Swakopmund, Namibia.

BIGGS, D. (2013) Will selling rhino horns (legally) save the rhino? Tackling Africa's rhino poaching crisis. Decision Point, 69, 6-7.

Biggs, D., Courchamp, F., Martin, R. \& Possingham, H.P. (2013) Legal trade of Africa's rhino horns. Science, 339, 1038-1039.

Brockington, D. (2002) Fortress Conservation: The Preservation of the Mkomazi Game Reserve, Tanzania. James Currey, Martlesham, UK.

Brodie, J.F., Muntifering, J., Hearn, M., Loutit, B., Loutit, R., Brell, B. et al. (2011) Population recovery of black rhinoceros in north-west Namibia following poaching. Animal Conservation, 14, 354-362.

Brooks, J.S., WAYLen, K.A. \& Borgerhoff, M. (2012) How national context, project design, and local community characteristics influence success in community-based conservation projects. Proceedings of the National Academy of Sciences of the United States of America, 109, 21265-21270.

Brown, V.A., Harris, J.A. \& Russell, J.A. (eds) (2010) Tackling Wicked Problems: Through the Transdisciplinary Imagination. Earthscan, London, UK.

Buckley, R. (ed.) (2010) Conservation Tourism. CABI, Wallingford, UK.

Challender, D.W.S. \& MacMillan, D.C. (2014) Poaching is more than an enforcement problem. Conservation Letters, 7 , 484-494.

Clark, S.G. (2002) The Policy Process: A Practical Guide for Natural Resources Professionals. Yale University Press, New Haven, USA.

Coghlan, A. (2014) Campaign blunts Vietnamese demand for rhino horn. New Scientist. Http://www.newscientist.com/article/ dn26415-campaign-blunts-vietnamese-demand-for-rhino-horn. html\#.VSpaGfnF9Qg [accessed 11 April 2015].

Cowling, R.M. (2014) Let's get serious about human behavior and conservation. Conservation Letters, 7, 147-148.

Dowie, M. (2009) Conservation Refugees: The Hundred-year Conflict between Global Conservation and Native Peoples. MIT Press, Cambridge, USA.

Dressler, W. \& BÜscher, B. (2008) Market triumphalism and the CBNRM 'crises' at the South African section of the Great Limpopo Transfrontier Park. Geoforum, 39, 452-465.

Duffy, R., Emslie, R.H. \& Knight, M.H. (2013) Rhino Poaching: How Do We Respond? Evidence on Demand, Hemel Hempstead, UK.

Ferraro, P.J. \& Hanauer, M.M. (2014) Quantifying causal mechanisms to determine how protected areas affect poverty through changes in ecosystem services and infrastructure. Proceedings of the National Academy of Sciences of the United States of America, 111, 4332-4337.

Ferreira, S.M. \& OKITA-OUMA, B. (2012) A proposed framework for short-, medium- and long-term responses by range and consumer States to curb poaching for African rhino horn. Pachyderm, 51, $52-60$.

Hearn, M., Kruger, B. \& Brett, R. (2004) Stakeholder Workshop on Biological Management Options for the Black Rhino in Northwest Namibia. SADC Regional Programme for Rhino Conservation, Harare, Zimbabwe. 
Hohl, A. \& Clark, S.G. (2010) Best practices: the concept, an assessment, and recommendations. In Large Scale Conservation: Integrating Science, Management, and Policy in the Common Interest, 24th edition (eds S.G. Clark, A. Hohl, C.H. Picard \& D. Newsome), pp. 151-170. Yale School of Forestry and Environmental Studies, New Haven, USA.

Hoole, A.F. (2010) Place-power-prognosis: community-based conservation, partnerships, and ecotourism enterprises in Namibia. International Journal of the Commons, 4, 78-99.

IUCN (2014) The IUCN Red List of Threatened Species v. 2014.3. Http://www.iucnredlist.org [accessed 22 March 2015].

iUCN, SUli, IIED, CEED, Austrian Ministry of Environment \& TRAFFIC (eds) (2015) Beyond Enforcement: Communities, Governance, Incentives, and Sustainable use in Combating Wildife Crime. Symposium report. IIED, London, UK.

Jones, B. (2010) Ostrom and Namibian conservancies. Current Conservation, 4, 21-23.

Jones, B. \& Murphree, M. (2001) The evolution of policy on community conservation in Namibia and Zimbabwe. In African Wildlife and Livelihoods: The Promise and Performance of Community Conservation (eds D. Hulme \& M. Murphree), pp. 3858. James Currey, Martlesham, UK.

Jones, B.T.B., Diggle, R.W. \& Thouless, C. (2015) Institutional arrangements for conservation, development and tourism in Eastern and Southern Africa. In Institutional Arrangements for Conservation, Development and Tourism in Eastern and Southern Africa (eds R. van der Duim, M. Lamers \& J. van Wijk), pp. 17-38. Springer, Dordrecht, Netherlands.

Kahler, J.S. \& Gore, M.L. (2012) Beyond the cooking pot and pocket book: factors influencing noncompliance with wildlife poaching rules. International Journal of Comparative and Applied Criminal Justice, 36, 103-120.

Kahneman, D. (2011) Thinking, Fast and Slow. Penguin Group, London, UK.

Keane, A., Jones, J.P.G., Edwards-Jones, G. \& Milner-Gulland, E.J. (2008) The sleeping policeman: understanding issues of enforcement and compliance in conservation. Animal Conservation, $11,75-82$.

Knight, M. (2012) African Rhino Specialist Group report. Pachyderm, $52,7-19$.

Lasswell, H.D. (1943) Power and Personality. W.W. Norton, New York, USA.

Lasswell, H.D. (1971) A Pre-View of Policy Sciences. American Elsevier, New York, USA.

Lasswell, H.D. \& Holmberg, A.R. (1992) Toward a general theory of directed value accumulation and institutional development. In Jurisprudence for a Free Society: Studies in Law, Science and Policy (eds H.D. Lasswell \& M.S. McDougal), pp. 1379-1417. New Haven Press, New Haven, USA.

Lejano, R.P., Ingram, H.M., Whiteley, J.M., Torres, D. \& Agduma, S.J. (2007) The importance of context: integrating resource conservation with local institutions. Society and Natural Resources, 20, $177-185$.

Loutit, R. \& Owen-Smith, G. (1989) The Auxiliary Game Guard System in north-western Namibia and its role in black rhinoceros (Diceros bicornis) conservation. Koedoe, 2, 85-86.

Maslow, A. (1954) Motivation and Personality. Harper, New York, USA.

Mason, C.F., Bulte, E.H. \& Horan, R.D. (2012) Banking on extinction: endangered species and speculation. Oxford Review of Economic Policy, 28, 180-192.

Mattson, D., Karl, H. \& Clark, S. (2012) Values in natural resource management and policy. In Restoring Lands-Coordinating Science,
Politics and Action (eds H. Karl, L. Scarlett, J.C. Vargas-Moreno \& M. Flaxman), pp. 239-259. Springer, New York, USA.

McKenzie-Mohr, D. (200o) Promoting sustainable behavior: an introduction to community-based social marketing. Journal of Social Issues, 56, 543-554.

Messer, K.D. (2010) Protecting endangered species: when are shoot-on-sight policies the only viable option to stop poaching? Ecological Economics, 69, 2334-2340.

MET (Ministry of Environment and Tourism) (2013) Guidelines for Mangement of Conservancies and Standard Operating Procedures. MET, Windhoek, Namibia.

Milgroom, J. \& Spierenburg, M. (2008) Induced volition: resettlement from the Limpopo National Park, Mozambique. Journal of Contemporary African Studies, 26, 435-448.

Milner-Gulland, E.J. \& Leader-Williams, N. (1992) A model of incentives for the illegal exploitation of black rhino and elephants: poaching pays in Luangwa Valley, Zambia. Journal of Applied Ecology, 29, 388-401.

Muntifering, J.R., Намbo, B., /Uiseb, K.H. \& du Preez, P. (2015) The Rhino Ranger Incentive Programme, Namibia. In Conservation, Crime and Communities: Case Studies of Efforts to Engage Local Communities in Tackling Illegal Wildlife Trade (ed. D. Roe), pp. 26-29. IIED, London, UK.

NACSO (ed.) (2014) The State of Community Conservation in Namibia: A Review of Communal Conservancies, Community Forests and Other CBNRM Initiatives (2013 Annual Report). NACSO, Windhoek, Namibia.

National Planning Commission (2007) Kunene Regional Poverty Profile. National Planning Commission, Windhoek, Namibia.

Neumann, R.P. (2004) Moral and discursive geographies in the war for biodiversity in Africa. Political Geography, 23, 813-837.

Ostrom, E. (1990) Governing the Commons. Cambridge University Press, New York, USA.

Ostrom, E. (200o) Collective action and the evolution of social norms. The Journal of Economic Perspectives, 14, 137-158.

Ostrom, E. (2007) A diagnostic approach for going beyond panaceas. Proceedings of the National Academy of Sciences of the United States of America, 104, 15181-15187.

Owen-Smith, G. (2010) An Arid Eden: A Personal Account of Conservation in the Kaokoveld. Jonathon Ball Publishers, Johannesburg, South Africa.

Putnam, R.D. (2000) Bowling Alone: The Collapse and Revival of American Community. Simson \& Schuster, New York, USA.

Rittel, H.W.J. \& Webber, M.M. (1973) Dilemmas in a general theory of planning. Political Science, 4, 155-169.

SChWARTZ, S.H. \& Bilsky, W. (1987) Towards a universal psychology structure of human values. Journal of Personality and Social Psychology, 53, 550-562.

Shogren, J.F. (2012) Behavioural Economics and Environmental Incentives. OECD Environment Working Papers 49. OECD Publishing, Paris, France.

Smith, R.J., Verissimo, D., Leader-Williams, N., Cowling, R.M. \& KNight, A.T. (2009) Let the locals lead. Nature, 462, 280-281.

Standley, S. \& Emslie, R.H. (2013) Population and Poaching of African Rhinos across African Range States. Evidence on Demand, Hemel Hempstead, UK.

STEG, L. \& VLEK, C. (2009) Encouraging pro-environmental behaviour: an integrative review and research agenda. Journal of Environmental Psychology, 29, 309-317.

Stern, P.C., Dietz, T., Abel, T.D., Guagnano, G.A. \& Kalof, L. (1999) A value-belief-norm theory of support for social movements: the case of environmentalism. Human Ecology Review, 6, 81-97. 
Sullivan, S. (2002) How sustainable is the communalizing discourse of 'new' conservation? The masking of difference, inequality and aspiration in the fledgling 'conservancies' of Namibia. In Conservation and Mobile Indigenous Peoples: Displacement, Forced Settlement and Sustainable Development (eds D. Chatty \& M. Colchester), pp. 158-187. Berghahn, Oxford, UK.

Sullivan, S. \& Homewood, K. (2004) Natural resources: use, access, tenure and management. In Eastern and Southern Africa: Development Challenges in a Volitile Region (eds D. Potts \& T. Bowyer-Bower), pp. 118-166. Pearson Education Ltd, London, UK.

/Uiseb, K.H. (2007) Attitudes and perceptions of the local community towards the re-introduced black rhino in the Khoadi Hôas conservancy in the north-west of Namibia. MSc thesis. University of the Free State, Bloemfontein, South Africa.

! URI- $\neq$ Кно в, S. (2004) Attitudes and perceptions of local communities towards the reintroduction of black rhino (Diceros bicornis bicornis) into their historical range in northwest Kunene Region, Namibia. MSc thesis. University of Kent, UK.

!Uri- $\neq$ Khob, S., Muntifering, J.R., Du Preez, P., Beytell, P., Uiseb, K. \& Loutit, R. (2010) Namibia's desert-rhino renaissance. In Conservation and the Environment in Namibia (ed. R. van Schalkwyk), pp. 24-25. Venture Publications, Windhoek, Namibia.

Young, M.D. \& Gunningham, N. (1997) Mixing instruments and institutional arrangements for optimal biodiversity conservation.
In Conservation Outside Nature Reserves (eds P. Hale \& D. Lamb), pp. 123-135. Center for Conservation Biology, University of Queensland, Australia.

\section{Biographical sketches}

JefF MUntifering is a conservation biologist who has worked on community-based rhinoceros conservation in Namibia for 12 years. WAYNE LINKLATER's research focuses on the ecology, behaviour and management of wildlife. SUSAN C L ARK is an expert on policy science. SimSON !URI- $\neq$ Kнов leads rhinoceros monitoring operations. JOHN KASAONA works to improve community-based conservation strategies. Kenneth /Uiseb has researched community attitudes towards rhinoceroses. Pierre Du PreEz is Namibia's National Rhino Coordinator. KAPOI KASAONA has worked in rhinoceros conservation and tourism. Petrus Beytell's research focuses on rhinoceros, lion and crocodile ecology. JER M A IN KETJ leads community engagement for private-sector tourism. B о As Н а м во is a guide and leads the Rhino Ranger Support Group. Matthew Brown is Conservation Director for The Nature Conservancy's Africa Programme. Chris THOULESs leads support services for community conservation projects. Shayne Jacobs' research focuses on ecosystem ecology. ANDREW KNIGHT's research focuses on improving conservationrelated decision making. 